\title{
Regras e Contexto: As Reformas da Constituição de $1988^{*}$
}

Celina Souza

\section{INTRODUÇÃO}

D or que mudam as instituições e por que, como e em que matérias 1 ocorreram mudanças na Constituição de 1988? Explicar mudanças institucionais tem sido reconhecido como uma das questões empíricas e teóricas mais complexas. Ademais, constituições são consideradas instituições (regras) desenhadas para serem duradouras, estáveis e pouco suscetíveis a mudança. A Constituição brasileira de 1988 e suas 62 emendas (56 emendas constitucionais e seis de revisão) oferecem ao pesquisador a rara oportunidade de analisar por que e em que direções ocorreram tantas mudanças nesses vinte anos de vigência, ou seja, desde sua promulgação, a Constituição foi emendada a uma taxa média anual de 3,1 emendas.

Este artigo busca respostas para essa questão analisando-a por meio de um partido analítico que conjuga as contribuições da literatura sobre mudança institucional com hipóteses de uma teoria sobre emendas constitucionais. Do ponto de vista empírico, os testes de hipóteses sobre por que ocorrem mudanças institucionais e sobre emendas às constituições ainda são escassos e apresentam conclusões divergentes. No caso das reformas à Constituição de 1988, ainda existem poucos estu-

\footnotetext{
* Agradeço a Flávio Fontanelli, a Eduardo Marques e a um dos pareceristas anônimos da revista $D A D O S$ os excelentes e pertinentes comentários.

DADOS - Revista de Ciências Sociais, Rio de Janeiro, Vol. 51, nº 4, 2008, pp. 791 a 823.
} 
dos de cientistas políticos ${ }^{1}$. Essa lacuna começa a ser preenchida neste ano em virtude da comemoração dos 20 anos da promulgação da Constituição, que tem atraído a atenção de pesquisadores de diversas áreas².

Embora este artigo não compare as mudanças na Constituição brasileira com as de outros países, apesar de a eles fazer referências, a análise de apenas um caso - o do Brasil - não significa a defesa de sua peculiaridade. Pelo contrário, há muito pouco de singular ou de marcadamente atípico no caso brasileiro. Nesse sentido, busca-se contribuir para preencher a lacuna sobre como e por que ocorreram mudanças na Constituição de 1988, na tentativa de trazer informações e análises mais detalhadas que permitam futuras comparações. Dado esse objetivo, não são analisadas questões como os conflitos políticos causados pelas propostas de reformas, a importância ou não dos pontos de veto do sistema político brasileiro, tampouco são mensuradas as conseqüências políticas e econômicas das reformas constitucionais.

São testadas duas hipóteses, uma institucional e uma de causalidade. A hipótese institucional assume que as regras da Constituição de 1988 refletem as incertezas dos constituintes, naquele "momento crítico", sobre temas como modelo econômico, políticas fiscais e políticas sociais. Essas incertezas tiveram duas conseqüências: 1) os requisitos para emendas à Constituição são relativamente fáceis de serem cumpridos;2) com a ampliação da competência privativa da União para legislar, os constituintes delegaram ao Legislativo e ao Executivo federais a determinação das preferências sociais futuras e a tarefa de tornarem efetivos os direitos sociais constitucionalizados em 1988. A segunda hipótese remete à causalidade das mudanças, ou seja, a constitucionalização de inúmeras matérias (tributárias, direitos sociais e modelo econômico) foi seguida de mudanças nos contextos macroeconômico e político. Essas mudanças foram iniciadas e/ou consolidadas nos mandatos dos presidentes Fernando Henrique Cardoso e Luiz Inácio Lula da Silva. Das 56 emendas constitucionais já promulgadas, 52 ocorreram no decorrer dos mandatos desses dois presidentes. Essas emendas redesenharam o sistema tributário e o modelo econômico, e viabilizaram a transformação de alguns direitos sociais em políticas e ações.

Para responder à questão da pesquisa e testar suas duas hipóteses, a taxa de "emendamento" da Constituição de 1988 é tratada como variável dependente, sendo variáveis explicativas o ano de promulgação 
das emendas; emendas por presidente; iniciativa; número de palavras; constitucionalização; e contexto/conjuntura política e econômica. Taxa de "emendamento" é um indicador proposto por Lutz (1994) para investigar a probabilidade de a Constituição ser totalmente ou muitas vezes refeita, ou a probabilidade de que mudanças estejam ou tenham sido feitas por meios extraconstitucionais, como controle de constitucionalidade (judicial review). A taxa de "emendamento" é encontrada pela divisão do número de emendas pelo número de anos da Constituição. Na impossibilidade de quantificar todas as mudanças constitucionais, o desafio neste estudo é analítico, ou seja, identificar e explicar seus principais fatores e causas.

Argumenta-se que a Constituição de 1988 resultou do momento político marcado pelo objetivo de tornar crível e de legitimar o novo sistema democrático, visto que ela mesma foi desenhada antes do fim da transição. Por essa razão, os constituintes fizeram três opções que, posteriormente, facilitariam a aprovação das reformas constitucionais: 1) tornar as regras de "emendamento" relativamente fáceis de serem cumpridas; 2) aumentar a constitucionalização de muitas matérias; 3) aumentar o número de matérias de competência legislativa privativa da União. Essas decisões, aliadas à mudança no contexto macroeconômico e político a partir dos anos 1990, tornaram a Constituição de 1988, além da mais emendada Constituição brasileira, uma das mais emendadas do mundo.

No entanto, a onda reformista não afetou toda a Constituição e, não por acaso, das 62 emendas constitucionais, apenas duas (duração do mandato dos ocupantes de cargos do Executivo e reeleição para o Executivo) mudaram as regras iniciais aplicáveis ao sistema político. Já o desenho das políticas públicas caminhou na direção oposta à da estabilidade. Isso porque, dado o objetivo dos constituintes em legitimar a redemocratização, negociações e barganhas referentes às políticas públicas e que encaminhassem alternativas para questões que afetavam as condições sociais da população, o desempenho macroeconômico e o modelo econômico do país foram marcados por incertezas e dificuldades de negociação naquele "momento crítico" (Souza, 1997; 2001; 2005). As emendas promulgadas a partir dos anos 1990 buscaram, então, mudar a rota das políticas macroeconômicas, do modelo econômico e do sistema tributário, assim como pôr em prática direitos sociais constitucionalizados. Contudo, e diferentemente do que ocorreu com o sistema político, das 27 emendas que promoveram mudanças nas 
políticas públicas, sobretudo fiscal e social, mais da metade, ou seja, dezesseis (59\%) têm vigência datada, total ou parcialmente.

Este artigo está dividido em duas partes. A primeira mapeia as contribuições da literatura teórica sobre o tema das mudanças institucionais em geral e das constitucionais em particular. Na segunda, são analisadas as 62 emendas promulgadas entre 1992 e dezembro de 2008 (56 emendas constitucionais e seis de revisão) à luz das variáveis listadas anteriormente. Em seguida, são apresentadas algumas conclusões.

\section{POR QUE MUDAM AS INSTITUIÇÕES?}

No campo da análise institucional, muitos afirmam a inexistência de uma teoria geral capaz de criar hipóteses sobre por que mudam as instituições (Rothstein, 1998:153), embora isso não elimine a possibilidade de que mudanças sejam incorporadas às teorias sobre desenho institucional (Goodin, 1998). Mudanças institucionais ocorrem e têm sido exaustivamente analisadas, em geral por meio de tipologias que buscam explicar suas causas, as quais são traduzidas em modelos: evolução (biológica, social), contratação/recontratação e liderança ${ }^{3}$. Goodin (ibidem:24), inspirado em estudo anterior de Jon Elster (1983), classifica as mudanças como decorrentes de acidente (contingência), evolução (mudanças aleatórias, mas limitadas por mecanismos que selecionam aquelas com melhor capacidade de adaptação) e intenção (intervenção intencional de um indivíduo ou de grupos organizados).

A despeito das controvérsias teóricas e empíricas sobre mudanças institucionais, existe consenso na literatura neo-institucionalista sobre alguns pontos. O primeiro é que mudanças institucionais raramente decorrem de apenas um modelo, mas de sua combinação. O segundo é que mudanças institucionais são processos incrementais realizados por intermédio de interações estratégicas. O terceiro é que o presente é marcado pelo passado, condicionando as ações no presente e as escolhas futuras.

\section{POR QUE E COMO MUDAM AS CONSTITUIÇÕES?}

Questões teóricas e operacionais sobre mudanças constitucionais não são triviais e implicam considerações normativas (qual é o grau ideal de mudança) e empíricas (que fatores produzem mudanças, qual é a capacidade do governo de implementar os dispositivos constitucionais, entre outras). Essas questões geram tensões de várias ordens, in- 
clusive entre regras sobre mudanças versus regras que preservem princípios democráticos universais.

A literatura que discute se as constituições devem ser flexíveis ou rígidas em relação a mudanças chega a conclusões divergentes. De um lado estão os que advogam a rigidez com argumentos extraídos da literatura sobre escolha pública como forma de impedir arbitrariedades do Executivo e a perpetuação de chefes do Executivo, assim como impedir alterações abruptas que ameacem os interesses dos agentes econômicos etc. (Buchanan e Tullock, 1962; North e Weingast, 1989; Riker, 1982). De outro lado estão os que argumentam a favor da flexibilidade porque mudanças são inevitáveis e ocorrem por várias razões, entre elas, como forma de adaptação a novas circunstâncias; por necessidade de corrigir a limitada capacidade do conhecimento humano; para remediar conseqüências inesperadas; para não perpetuar injustiças; para não engessar as demandas das gerações futuras. Por isso, as constituições escritas determinam, em seu próprio texto, qual é o método para que mudanças ocorram. Se as constituições representam compromissos críveis assumidos nos momentos fundadores ou refundadores de uma nação, esses compromissos não eliminam imperfeições e, nas palavras de Ferejohn (1997), regras sobre mudanças são formas de encontrar acomodações práticas, embora sempre imperfeitas, para os conflitos políticos ${ }^{4}$.

Apesar do relativo consenso sobre a importância de mecanismos que corrijam as imperfeições das constituições, existem também, em todas elas, determinações sobre compromissos que não podem ser alterados, ou seja, as cláusulas pétreas, ou as matérias excluídas do conflito político pacífico ${ }^{5}$.

Constituições podem ser modificadas por quatro meios: emenda; mudanças periódicas de todo o texto constitucional; interpretação judicial; e revisão legislativa. As mudanças podem resultar de exclusiva decisão legislativa ou da combinação desta com a manifestação dos eleitores, de decisões do Judiciário ou da completa substituição da Constituição. A adoção de um desses quatro métodos faz diferença? A base dessa pergunta é saber se as regras definidas pelos constituintes para as revisões constitucionais fazem diferença na probabilidade de a Constituição ser alterada.

O teste empírico desses diferentes métodos, realizado por Lutz (1994), indica que cada método implica maior ou menor número de mudan- 
ças, assim como também reflete a visão dos constituintes sobre o texto constitucional, ou seja, se a Constituição é um documento definidor de direitos e princípios ou se é, além disso, reguladora de matérias que seriam objeto de legislação ordinária. As hipóteses testadas por Lutz (ibidem), que as aplicou tanto às constituições estaduais dos Estados Unidos quanto às constituições de 32 países, podem ser assim resumidas:

- Quanto mais fácil o método para a revisão, maior a taxa de "emendamento".

- Quanto maior o número de palavras, maior o número de emendas.

- Quanto maior a taxa de "emendamento", 1) menor a probabilidade de que a Constituição tenha o papel do que os juristas chamam de Lei Maior; 2) menor a probabilidade de que exista distinção entre matérias constitucionais e de legislação ordinária;3) maior a probabilidade de que o texto constitucional seja um tipo de código de regras; 4) maior a probabilidade de que o processo formal de emenda seja dominado pelo Legislativo.

A tese defendida por Lutz é a de que, quando os constituintes escolhem um determinado tipo de regra para emendar a Constituição, e quando optam por um determinado "modelo" de Constituição - se estabelece princípios, regras e direitos ou se também regula um amplo leque de políticas públicas, como é o caso da Constituição de 1988, caracterizando o que Lutz chamou de código de regras -, tais escolhas podem predizer o que ocorrerá com a Constituição.

Se a literatura sobre mudança constitucional privilegia o papel das regras para suas emendas (quórum, tipo de processo legislativo, poder de iniciativa, formas de aprovação), tamanho da Constituição e matérias constitucionalizadas como as variáveis mais importantes para predizer o grau das mudanças constitucionais, outros fatores também parecem assumir relevância, notadamente em países de democracia recente e que reescreveram suas constituições como parte do retorno ao sistema democrático. É o caso, por exemplo, do Brasil e dos países do Leste Europeu analisados por Roberts (no prelo). Uma dessas variáveis é o número de partidos representados no Legislativo, assumindo-se que menos partidos com maiores bancadas teriam mais facilidade para atingir as maiorias qualificadas exigidas para o processo de "emendamento". Outra variável pouco considerada na literatura é a mudança de contexto ou de conjuntura. Embora essas mudanças sejam 
sempre mencionadas, não são analisadas empiricamente, com raras exceções. A variável número de partidos e tamanho de suas bancadas não será aqui analisada, dado que, como se sabe, o Brasil tem, desde a redemocratização, grande número de partidos representados no Legislativo e nenhum detém maioria qualificada. Isso não impediu que a Constituição de 1988 fosse objeto de mais de três emendas por ano. A variável mudança de contexto/conjuntura, a qual se aplica tanto ao Brasil quanto aos países do Leste Europeu, será analisada adiante ${ }^{6}$.

\section{A CONSTITUIÇÃO DE 1988 E SUA REFORMA}

Desde a promulgação da Constituição de 1988, sua reforma esteve na agenda de vários organismos: governos, setores privados nacional e internacional e organismos multilaterais. A decisão dos constituintes de 1988 de tornar a revisão constitucional relativamente fácil, de constitucionalizar inúmeras matérias e as mudanças de contexto/conjuntura permitiram que a Constituição de 1988 fosse, até agora, a mais emendada Constituição brasileira, como já mencionado, registrando a maior taxa de "emendamento" em comparação com as anteriores (ver Tabela 1 abaixo).

\section{Tabela 1}

Emendas Constitucionais por Constituição

\begin{tabular}{l|c|c|c|c}
\hline $\begin{array}{l}\text { Promulgação da } \\
\text { Constituição (ano) }\end{array}$ & Término & $\begin{array}{c}\text { Duração } \\
\text { (anos) }\end{array}$ & $\begin{array}{c}\text { Número de } \\
\text { Emendas }\end{array}$ & $\begin{array}{c}\text { Taxa de } \\
\text { "Emendamento" }\end{array}$ \\
\hline 1891 & 1930 & 40 & 1 & 0,025 \\
1934 & 1937 & 3 & 1 & 0,333 \\
1937 & 1945 & 8 & 21 & 2,625 \\
1946 & 1967 & 21 & 27 & 1,285 \\
1967 & 1969 & 2 & 0 & - \\
1969 & 1988 & 19 & 26 & 1,368 \\
1988 & - & 20 & $62^{*}$ & 3,1 \\
\hline
\end{tabular}

Elaboração da autora baseada nos textos das constituições e em suas emendas (http://www. planalto.gov.br/ccivil_03/Constituicao/Constitui\%C3\%A7ao.htm).

*Cinqüenta e seis emendas constitucionais e seis de revisão.

Os constituintes de 1988 optaram por dois dos métodos listados por Lutz (1994) como forma para reformar a Constituição: revisão legislativa e emendas 7 . O primeiro, com prazo determinado, foi utilizado em 1994 com base no que estabeleceu o art. 3 do Ato das Disposições Constitucionais Transitórias - ADCT. O rito previsto na Constituição 
era voto da maioria absoluta, em sessão unicameral e turno único. Já o segundo método requer quórum qualificado (três quintos em duas votações nominais nas duas Casas legislativas), por meio do qual $56 \mathrm{mu}-$ danças foram aprovadas entre 1992 e $2008^{8}$. Além disso, os constituintes de 1988 mantiveram a tendência das constituições anteriores de inserir no corpo da Constituição um amplo leque de políticas públicas, muitas detalhadas no corpo constitucional, ampliando, por exemplo, a lista de disposições do título constitucional sobre a ordem social, assim como detalhando mais do que as constituições anteriores o título constitucional sobre tributação. Eles também promoveram uma inovação: a inclusão de um capítulo sobre direitos sociais, inexistente nas constituições anteriores ${ }^{9}$. Contudo, nisso também a Constituição de 1988 nada tem de peculiar. Como informa Hirschl (2004:125), muitas constituições e/ou cortes constitucionais reconhecem hoje direitos sociais, considerados positivos ou de segunda geração.

Dessas opções dos constituintes resultou a expansão das funções de governo, particularmente do governo federal. No entanto, como assinala Lijphart (1999) e relembra Melo (2007), constituições detalhadas são encontradas nos modelos consociativos de democracia e tendem a ser a opção em vários países federais. Como também mostram vários autores, existe tendência crescente para que questões que seriam objeto de legislação ordinária estejam hoje cada vez mais constitucionalizadas. A diferença é importante porque, uma vez constitucionalizadas, essas matérias passam a ser objeto de regras especiais e abrem espaço para decisões de conflito pelo Judiciário nos países que adotam o controle da constitucionalidade ${ }^{10}$. O que ressalta no caso brasileiro é a constitucionalização dos detalhes das políticas, notadamente as que transformam alguns direitos sociais em políticas, opção que continuou a guiar as emendas. Estão também constitucionalizados os papéis que cabem aos diferentes níveis de governo na formulação e na implementação de políticas públicas. Em termos comparativos, esse é o único aspecto peculiar do modelo constitucional brasileiro, dado que, como afirmam vários autores (Congleton, Kyriacou e Bacaria, 2003:169, por exemplo), a definição de autoridade sobre políticas públicas raramente é matéria constitucional.

Na verdade, a Constituição de 1988 nasceu sob a égide de sua própria revisão, prevista para ser convocada em 1993 (art. 3o do ADCT). O efeito prático desse mandamento constitucional é que mudanças poderiam ser feitas pela maioria absoluta, em turno único e em sessões uni- 
camerais. No entanto, e diferentemente do que previram os constituintes de 1988, a Constituição não foi inteiramente revista e apenas seis emendas de revisão foram aprovadas. Dessas emendas, duas merecem destaque: 1) a no 5, que reduziu o mandato dos ocupantes de cargos do Executivo de cinco para quatro anos, medida depois novamente modificada pela Emenda Constitucional - EC no 16, de 1997, que manteve o mandato de quatro anos, mas permitiu a reeleição; 2) a que instituiu o Fundo Social de Emergência - FSE, autorizando o governo federal a reter parcela de recursos constitucionalmente vinculados, aprofundando, assim, as restrições fiscais e tributárias aprovadas no ano anterior pela EC nํ 3 .

Para testar as duas hipóteses deste artigo, a taxa de "emendamento", complementada pelo índice de dificuldade para aprovar emendas, é a variável dependente, enquanto as variáveis seguintes, conforme já mencionado, são explicativas: ano da emenda; emendas por presidente; iniciativa; número de palavras; constitucionalização; mudanças no contexto/conjuntura política e macroeconômica.

OQuadro 1 e o Gráfico 1 a seguir apresentam um quadro geral de todas as emendas constitucionais e de revisão, agrupando-as por grandes objetivos.

Os dados do Gráfico 1 apontam para a inegável prevalência do tema fiscal na agenda das reformas. No entanto, e como mostram as informações do Quadro 1, se a reforma fiscal foi dirigida, em grande parte e nos primeiros anos, para o aumento da receita federal e para restringir despesa dos três níveis de governo, posteriormente muitas emendas também ampliaram as receitas das esferas subnacionais, notadamente dos municípios, compensando-os pelas vinculações de suas receitas determinadas sobretudo nas emendas sobre educação e saúde. Nesse último caso, as emendas que vincularam receitas das três esferas de governo tiveram o papel de tornar efetivos os direitos sociais que foram, pela primeira vez, constitucionalizados, daí porque foram rotuladas, no Quadro 1, de emendas cujo objetivo foi transformar direitos em políticas. Cabe destacar também a importância das emendas que promoveram reformulações no modelo econômico, todas dirigidas para a quebra de monopólios estatais e para a abertura ao capital privado, inclusive estrangeiro, de atividades econômicas em que sua participação era constitucionalmente proibida ou monopólio do setor público. Embora mudanças do modelo econômico tenham conseqüências sobre a 


\section{Quadro 1}

Emendas Constitucionais e de Revisão, 1992-2007

\begin{tabular}{|c|c|c|}
\hline Objetivo & $\begin{array}{l}\text { Ano/No da } \\
\text { Emenda }\end{array}$ & Tema \\
\hline \multirow{13}{*}{$\begin{array}{l}\text { Redesenho do siste- } \\
\text { ma tributário: ajuste } \\
\text { fiscal/redução de } \\
\text { despesa (federal, es- } \\
\text { tadual, municipal) }\end{array}$} & $2007 / 56$ & Desvinculação de Recursos da União - DRU \\
\hline & $2005 / 47$ & Reforma previdenciária \\
\hline & $2003 / 42$ & Reforma tributária \\
\hline & $2003 / 41$ & Reforma previdenciária dos servidores públicos \\
\hline & $2000 / 27$ & DRU \\
\hline & $2000 / 25$ & Limitação de despesas: vereadores e legislativo municipal \\
\hline & $1998 / 20$ & Reforma previdenciária \\
\hline & $1997 / 17$ & $\begin{array}{l}\text { Fundo de Estabilização Fiscal-FEF e institui um adicional } \\
\text { de compensação financeira para os municípios }\end{array}$ \\
\hline & $1996 / 15$ & Regras para criação de novos municípios \\
\hline & $1996 / 10$ & $\mathrm{FEF}$ \\
\hline & 1994/R1 & FSE \\
\hline & $1993 / 3$ & $\begin{array}{l}\text { Reforma tributária: institui Imposto Provisório sobre Mo- } \\
\text { vimentação Financeira - IPMF; exclui Imposto de Renda - } \\
\text { IR estadual e Imposto sobre a Venda a Varejo de Combus- } \\
\text { tíveis Líquidos e Gasosos - IVVCLG municipal (1); limita } \\
\text { emissão de títulos por Estados e municípios; contribuição } \\
\text { de servidores públicos para suas aposentadorias e pen- } \\
\text { sões }\end{array}$ \\
\hline & $1992 / 1$ & Limite de despesas: deputados estaduais e vereadores \\
\hline \multirow{13}{*}{$\begin{array}{l}\text { Redesenho do siste- } \\
\text { ma tributário: au- } \\
\text { mento de receita (fe- } \\
\text { deral, estadual, mu- } \\
\text { nicipal) }\end{array}$} & $2007 / 55$ & Aumento de Fundo de Participação dos Municípios - FPM \\
\hline & $2004 / 44$ & $\begin{array}{l}\text { Aumento de } 4 \% \text { da Contribuição de Intervenção no Domí- } \\
\text { nio Econômico - Cide para Estados }\end{array}$ \\
\hline & $2004 / 43$ & $\begin{array}{l}\text { Recursos federais para irrigação no Centro-Oeste - CO e } \\
\text { no Nordeste - NE }\end{array}$ \\
\hline & $2003 / 42$ & Partilha da Cide com Estados e municípios \\
\hline & $2002 / 39$ & Taxa de iluminação pública para municípios (2) \\
\hline & $2002 / 38$ & $\begin{array}{l}\text { Despesas de Polícias Militares - PMs de Rondônia transfe- } \\
\text { ridas para a União }\end{array}$ \\
\hline & $2002 / 37$ & $\begin{array}{l}\text { Contribuição Provisória sobre Movimentação Financeira } \\
\text { - CPMF (vinculada à saúde, previdência e Fundo de Com- } \\
\text { bate e Erradicação da Pobreza - FCEP) e amplia isenções }\end{array}$ \\
\hline & $2001 / 33$ & $\begin{array}{l}\text { Imposto sobre importação de petróleo para a União; am- } \\
\text { plia incidência do Imposto sobre Circulação de Mercado- } \\
\text { rias e Prestação de Serviços - ICMS (combustíveis e impor- } \\
\text { tação por pessoas físicas). Autoriza governos subnacio- } \\
\text { nais a instituir contribuição previdenciária para seus ser- } \\
\text { vidores }\end{array}$ \\
\hline & $2000 / 29$ & $\begin{array}{l}\text { Progressividade do Imposto Predial e Territorial Urbano- } \\
\text { IPTU (2) }\end{array}$ \\
\hline & $2000 / 27$ & $\begin{array}{l}\text { Exclui Fundo de Participação dos Estados - FPE, FPM, sa- } \\
\text { lário-educação e incentivos fiscais para o Norte - N, NE e } \\
\text { CO da DRU }\end{array}$ \\
\hline & $1999 / 21$ & CPMF (vinculada à previdência) \\
\hline & $1996 / 12$ & CPMF (vinculada à saúde) \\
\hline & $1993 / 3$ & $\begin{array}{l}\text { Contribuição dos servidores aposentados e pensionistas } \\
\text { da União }\end{array}$ \\
\hline
\end{tabular}


Quadro 1

Emendas Constitucionais e de Revisão, 1992-2007 (continuação)

\begin{tabular}{|c|c|c|}
\hline Objetivo & $\begin{array}{l}\text { Ano/No da } \\
\text { Emenda }\end{array}$ & Tema \\
\hline $\begin{array}{l}\text { Redesenho do mo- } \\
\text { delo econômico } \\
\text { (quebra do monopó- } \\
\text { lio da União e dos } \\
\text { Estados / abertura } \\
\text { para o capital priva- } \\
\text { do) }\end{array}$ & $\begin{array}{l}2006 / 49 \\
2003 / 40 \\
2002 / 36 \\
1996 / 13 \\
1995 / 9 \\
1995 / 8 \\
1995 / 7 \\
1995 / 6 \\
1995 / 5\end{array}$ & $\begin{array}{l}\text { Radioisótopos e minerais } \\
\text { Capital estrangeiro no sistema financeiro nacional } \\
\text { Empresas jornalística e de radiodifusão } \\
\text { Atividades de resseguro } \\
\text { Exploração de petróleo } \\
\text { Telecomunicações e radiodifusão } \\
\text { Transportes e navegação de cabotagem } \\
\text { Recursos minerais } \\
\text { Gás canalizado }\end{array}$ \\
\hline $\begin{array}{l}\text { Redesenho dos siste- } \\
\text { mas eleitoral e políti- } \\
\text { co }\end{array}$ & $\begin{array}{l}2006 / 52 \\
1999 / 23 \\
1999 / 22 \\
1997 / 16 \\
1994 / R 5 \\
1994 / R 4 \\
1993 / 4 \\
1992 / 2\end{array}$ & $\begin{array}{l}\text { Partidos políticos e coligações partidárias (3) } \\
\text { Foro privilegiado para membros do Executivo federal } \\
\text { Habeas corpus no Superior Tribunal Federal - STF para } \\
\text { membros eletivos federais e membros do Executivo } \\
\text { Reeleição para cargos do Executivo } \\
\text { Mandato de quatro anos para cargos do Executivo } \\
\text { Inelegibilidade para ocupantes de cargos eletivos } \\
\text { Vigência de lei que altere o processo eleitoral } \\
\text { Plebiscito sobre forma e sistema de governo }\end{array}$ \\
\hline $\begin{array}{l}\text { Redesenho do Judi- } \\
\text { ciário (federal, esta- } \\
\text { dual), do Legislativo } \\
\text { federal e de instru- } \\
\text { mentos legais }\end{array}$ & $\begin{array}{l}2006 / 50 \\
2004 / 45 \\
2001 / 35 \\
2000 / 28 \\
1999 / 24 \\
1999 / 22 \\
1994 / \text { R6 } \\
1993 / 3\end{array}$ & $\begin{array}{l}\text { Funcionamento do Congresso } \\
\text { Reforma do Judiciário } \\
\text { Inviolabilidade civil e penal de membros do Congresso e } \\
\text { foro do STF } \\
\text { Prazo prescricional para ações trabalhistas } \\
\text { Justiça do Trabalho } \\
\text { Justiça Federal } \\
\text { Perda de mandato parlamentar } \\
\text { Ações no STF e efeito vinculante }\end{array}$ \\
\hline $\begin{array}{l}\text { Redesenho da rela- } \\
\text { ção Executivo-Le- } \\
\text { gislativo }\end{array}$ & $\begin{array}{l}2001 / 32 \\
1995 / 7 \\
1995 / 6 \\
1994 / \mathrm{R} 2\end{array}$ & $\begin{array}{l}\text { Medidas Provisórias - MPs e criação de cargos no Executi- } \\
\text { vo } \\
\text { MPs } \\
\text { MPs } \\
\text { Convocação de membros do Executivo pelo Congresso }\end{array}$ \\
\hline $\begin{array}{l}\text { Transformação de } \\
\text { direitos em políticas }\end{array}$ & $\begin{array}{l}2000 / 31 \\
2000 / 29 \\
1996 / 14\end{array}$ & $\begin{array}{l}\text { Fundo de Manutenção e Desenvolvimento da Educação } \\
\text { Básica e de Valorização dos Profissionais da Educação - } \\
\text { Fundeb } \\
\text { Fundo de Combate e Erradicação da Pobreza } \\
\text { Saúde pública } \\
\text { Educação fundamental e Fundo de Manutenção e Desen- } \\
\text { volvimento do Ensino Fundamental e de Valorização do } \\
\text { Magistério - Fundef }\end{array}$ \\
\hline $\begin{array}{l}\text { Redesenho da admi- } \\
\text { nistração pública }\end{array}$ & $\begin{array}{l}2006 / 51 \\
2001 / 34 \\
2000 / 30 \\
1999 / 23 \\
1998 / 19 \\
1998 / 18\end{array}$ & $\begin{array}{l}\text { Contratação de servidores da saúde } \\
\text { Médicos } \\
\text { Pagamento de precatórios } \\
\text { Criação do Ministério da Defesa } \\
\text { Reforma administrativa } \\
\text { Regime constitucional dos militares }\end{array}$ \\
\hline
\end{tabular}

(continua) 
Quadro 1

Emendas Constitucionais e de Revisão, 1992-2007 (continuação)

\begin{tabular}{|c|c|c|}
\hline Objetivo & $\begin{array}{l}\text { Ano/No da } \\
\text { Emenda }\end{array}$ & Tema \\
\hline $\begin{array}{l}\text { Desenho da política } \\
\text { cultural }\end{array}$ & $2005 / 48$ & Diretrizes do Plano Nacional de Cultura \\
\hline $\begin{array}{l}\text { Ampliação de direi- } \\
\text { tos sociais }\end{array}$ & $2000 / 26$ & Inclui moradia como direito social \\
\hline \multirow{4}{*}{$\begin{array}{l}\text { Correção de equí- } \\
\text { vocos/"áreas cin- } \\
\text { zentas" }\end{array}$} & $2007 / 54$ & Nacionalidade \\
\hline & $2005 / 46$ & Ilhas sede de município \\
\hline & 1996/11 & $\begin{array}{l}\text { Admissão de estrangeiros nas universidades e nos } \\
\text { centros de pesquisa }\end{array}$ \\
\hline & 1994/R3 & Nacionalidade \\
\hline
\end{tabular}

Elaboração da autora com base nas emendas à Constituição de 1988 (http:/ / www.planalto.gov. br/ccivil_03/Constituicao/Constitui\%C3\%A7ao.htm).

Notas:

(1) A exclusão do IR estadual também pode ser considerada uma emenda de correção de equívoco, dado que os tribunais o estavam julgando inconstitucional. A extinção do IVVCLG é conseqüência da exclusão dos combustíveis da cobrança de outros impostos, além do ICMS, do Imposto sobre Importação - II e do Imposto sobre Exportação - IE, determinada nessa mesma emenda.

(2) Essas emendas permitiram aos municípios cobrar a taxa de iluminação pública e alíquotas progressivas para o IPTU, as quais estavam sendo consideradas inconstitucionais pelos tribunais.

(3) A vigência dessa emenda foi adiada pelo STF.

\section{Gráfico 1}

Emendas por Temas

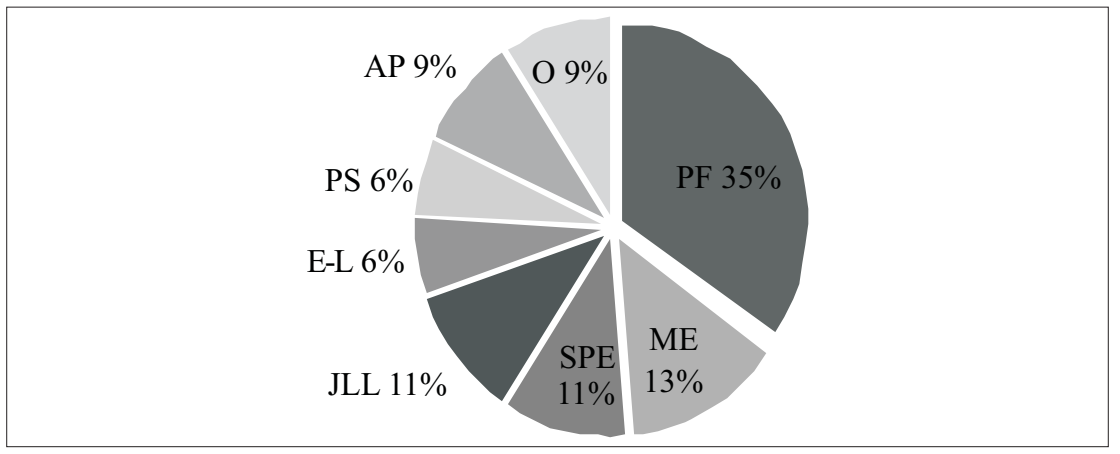

Elaboração da autora com base nas emendas à Constituição de 1988 (http://www.planalto.gov. br/ccivil_03/Constituicao/Constitui\%C3\%A7ao.htm).

Nota: Algumas emendas tratam de mais de um tema, razão pela qual o número de emendas acima ultrapassa 62.

Legenda:

PF: Política Fiscal;

ME: Modelo Econômico;

SPE: Sistema Político-Eleitoral;

JLL: Judiciário, Legislativo e Legislação;

E-L: Relação Executivo-Legislativo;

PS: Política Social;

AP: Administração Pública;

O: Outros. 
política fiscal, pela possível redução de despesas públicas, as mudanças realizadas no Brasil atenderam mais ao objetivo de reduzir o tamanho do setor público na economia e da abertura de alguns bens e serviços ao capital privado, nacional e estrangeiro, uma das demandas do paradigma da globalização, do que à redução de despesas propriamente dita.

\section{Taxa de “Emendamento"}

A Constituição brasileira de 1988 apresenta alta taxa de "emendamento" em face das constituições anteriores e de outros países pesquisados por Lutz (1994), Melo (2007) e Roberts (no prelo), atingindo um índice de 3,1, como já mencionado. Em comparação com outros países, essa é uma taxa alta. A taxa média dos países pesquisados por Lutz (1994) foi de 2,54; a das constituições dos estados norte-americanos, de 1,23. A média não ponderada dos países do Leste Europeu medida por Roberts foi de 0,39. Esse autor também analisou separadamente os artigos acrescidos, alterados ou excluídos, mostrando que, embora naqueles países a taxa de "emendamento" tenha sido baixa, muitas emendas promoveram mudanças significativas na quantidade de artigos e em outros, como no caso da Romênia, em que uma única emenda alterou quase a metade dos artigos da Constituição.

No entanto, a taxa de "emendamento" diz pouco sobre o tamanho e o significado das emendas. A taxa também contém limitações temporais, dado que é encontrada pela divisão do número de emendas pelo número de anos da Constituição, mudando, portanto, a cada ano. Indica, porém, que a Constituição original apresenta poucos obstáculos à mudança. Por essas razões, a taxa de "emendamento" é complementada pelo índice de dificuldade determinado pela Constituição para que ela seja modificada. Por esse indicador, a Constituição de 1988 é relativamente fácil de ser emendada, pelo pequeno número de votos requerido para sua aprovação em comparação com outros países - três quintos -, mas são exigidas votações nominais em dois turnos nas duas Casas legislativas. Aplicando o método de Lutz (1994) para medir o grau de dificuldade do processo de "emendamento", Melo (2007) calculou que a Constituição de 1988 apresenta um índice de 1,25, menor do que a de 1969, com índice de 1,5511. A redução deveu-se à diminuição do quórum requerido para a aprovação de emendas, de dois terços pela Constituição de 1967-1969 para três quintos ${ }^{12}$. Entre os 32 países pesquisados por Lutz (1994), a Constituição de 1988 estaria em quinto lugar em 
índice de dificuldade, tendo a média de todos os países alcançado $2,50^{13}$. Os mais baixos índices de dificuldade encontrados por Lutz (ibidem) foram os das constituições da Nova Zelândia $(0,50)$, Papua Nova Guiné $(0,77)$, Áustria e Portugal (ambas com 0,80 ). Os índices mais altos são os das constituições dos Estados Unidos $(5,10)$, Suíça $(4,75)$ e Austrália $(4,65)^{14}$. Em comparação com outros países da América Latina, o índice de dificuldade da Constituição de 1988 é o terceiro mais baixo (Melo, 2007). Quanto aos países do Leste Europeu analisados por Roberts (no prelo), a maioria exige quórum de dois terços, embora alguns países tenham outras exigências como referendo.

As regras para "emendamento" da Constituição de 1988 confirmam a hipótese de que, quanto mais fácil o método para a revisão constitucional, maior a taxa de "emendamento". Confirmam também a conclusão de Ferejohn (1997) de que, quanto menos complexo o processo legislativo, mais fácil será remediar o que os atores políticos identificaram como imperfeições ou lacunas na Constituição original.

\section{Ano das Emendas}

Essa variável - ano de promulgação da emenda - mostra que o maior número de reformas ocorreu nos dois primeiros anos dos mandatos do presidente Fernando Henrique Cardoso e dos legisladores; no caso do mandato de 1999 a 2002, o maior número foi registrado em 2000. Já no mandato do presidente Luiz Inácio Lula da Silva, o maior número de emendas - cinco - ocorreu no fim de seu primeiro mandato, em 2006, mas a reforma tributária aprovada em 2003 (EC no 42), primeiro ano de seu primeiro mandato, foi a que promoveu maior mudança nos artigos relativos ao sistema tributário (ver Quadro 1), tendo alterado vinte artigos.

Os números acima, mais bem visualizados no Gráfico 2, confirmam a hipótese de que os ocupantes dos cargos eletivos, respaldados pelo apoio eleitoral recém-conquistado, aproveitam os primeiros dois anos de seus mandatos para implementar sua agenda reformista. Confirmam também a hipótese institucionalista, isto é, a relativa facilidade do processo de "emendamento", a relativamente alta constitucionalização de matérias que seriam objeto de legislação ordinária e o poder de iniciativa do presidente facilitam mudanças constitucionais. No entanto, essas reformas foram motivadas, em sua maior parte, por mudanças no contexto/conjuntura que foram incorporadas pelas elites políticas de diferentes partidos à agenda reformista. 
Gráfico 2

Número de Emendas Constitucionais por Ano, 1992-2007

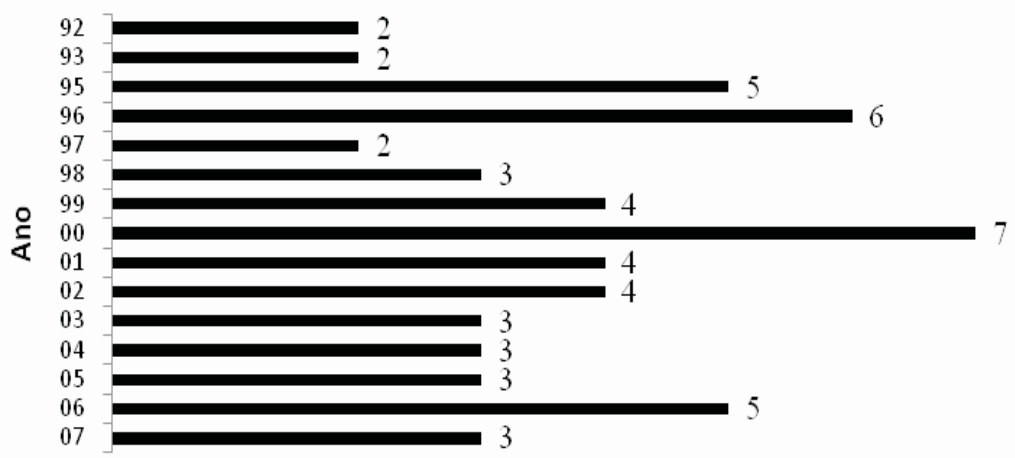

Elaboração da autora com base nas emendas à Constituição de 1988 (http://www.planalto.gov. br/ccivil_03/Constituicao/Constitui\%C3\%A7ao.htm).

O Gráfico 3 identifica a existência ou não de tendência temporal, mostrando, de forma agregada, a porcentagem e o número de emendas desde a promulgação da Constituição. As reformas constitucionais, iniciadas em 1992, tomaram ímpeto entre os cinco e os quinze anos da Constituição, diminuindo consideravelmente após esses anos. Podese dizer, portanto, que as emendas seguiram um padrão temporal, com as reformas fortemente concentradas entre os cinco e os quinze anos após a promulgação da Constituição, quando começaram a se consolidar as condições políticas e econômicas para a adoção de uma nova agenda macroeconômica e de política social. Conseqüentemente, nos primeiros cinco anos da Constituição, ainda não havia condições políticas e econômicas críveis para a proposição de emendas, e nos últimos cinco anos a agenda reformista parece relativamente estabilizada ${ }^{15}$.

\section{Emendas por Presidente em Exercício}

A variável emendas por presidente em exercício busca investigar se existe ou não diferença na agenda dos presidentes em relação às reformas constitucionais, além de discutir as principais hipóteses sobre a causalidade das mudanças - mudança de contexto / conjuntura (modelo de evolução) ou intervenção individual do presidente (liderança).

O Gráfico 4 demonstra que o ciclo das reformas constitucionais já está arrefecido, mas que os dois principais presidentes do período tiveram 
Gráfico 3

Freqüência das Emendas

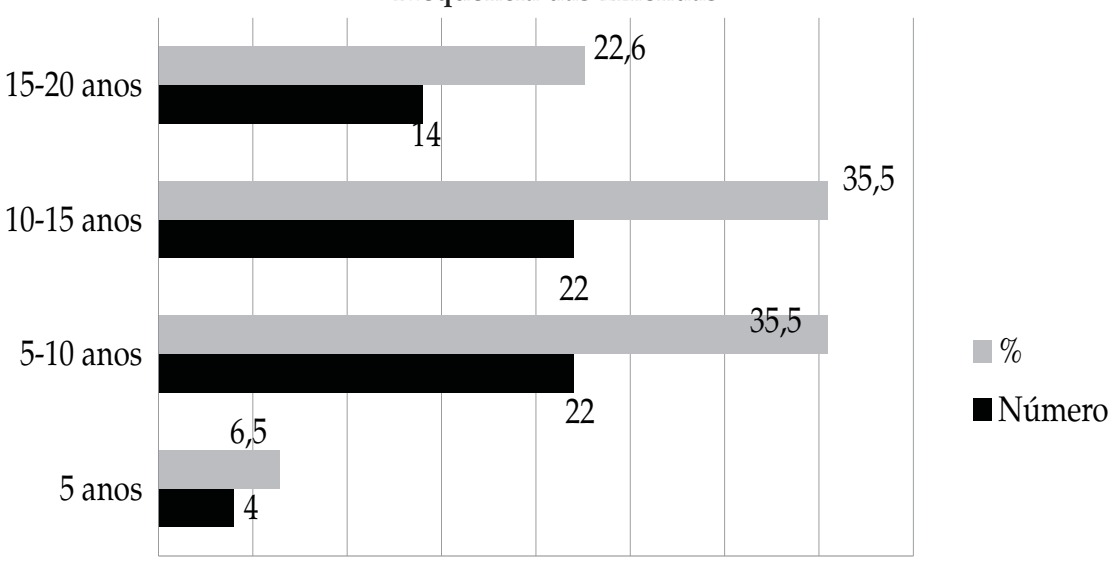

$\begin{array}{lllllllll}0 & 5 & 10 & 15 & 20 & 25 & 30 & 35 & 40\end{array}$

Elaboração da autora com base nas emendas à Constituição de 1988 (http://www.planalto.gov. br/ccivil_03/Constituicao/Constitui\%C3\%A7ao.htm).

\section{Gráfico 4}

Emendas Constitucionais e de Revisão por Presidente, 1992-2008

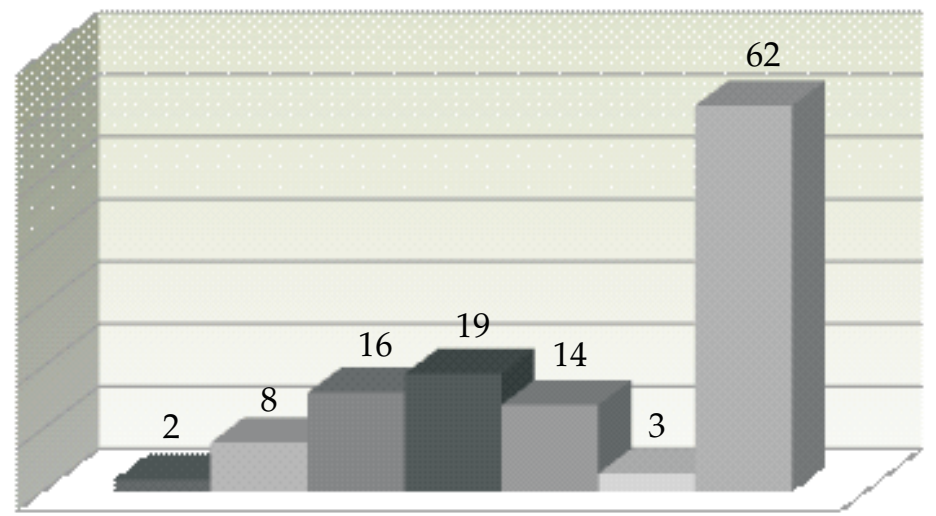

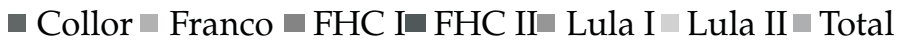

Elaboração da autora com base nas emendas à Constituição de 1988 (http://www.planalto.gov. br/ccivil_03/Constituicao/Constitui\%C3\%A7ao.htm).

agendas que implicavam emendas à Constituição, mesmo que muitas delas significassem tão-somente a renovação de emendas aprovadas anteriormente com período de tempo determinado, isto é, várias emendas que apenas confirmavam ou ampliavam regras aplicáveis às políticas fiscal e social. 
No que se refere à agenda dos presidentes, o Gráfico 5 mostra o número de emendas dos dois últimos presidentes por principais temas, ou seja, temas com impacto no redesenho do modelo econômico e nas políticas fiscal e social. Ambos os presidentes priorizaram a agenda fiscal, embora sob o mandato do presidente Fernando Henrique tenha havido maior número de emendas na área fiscal, o que era esperado diante da prioridade de seu governo concedida à política de estabilização financeira. As emendas desse período redesenharam os sistemas tributário e fiscal e serviram de ponto de partida para as emendas posteriores, as quais prorrogaram ou aprofundaram as medidas adotadas.

Gráfico 5

Emendas nos Mandatos de Fernando Henrique e Lula por Principais Temas

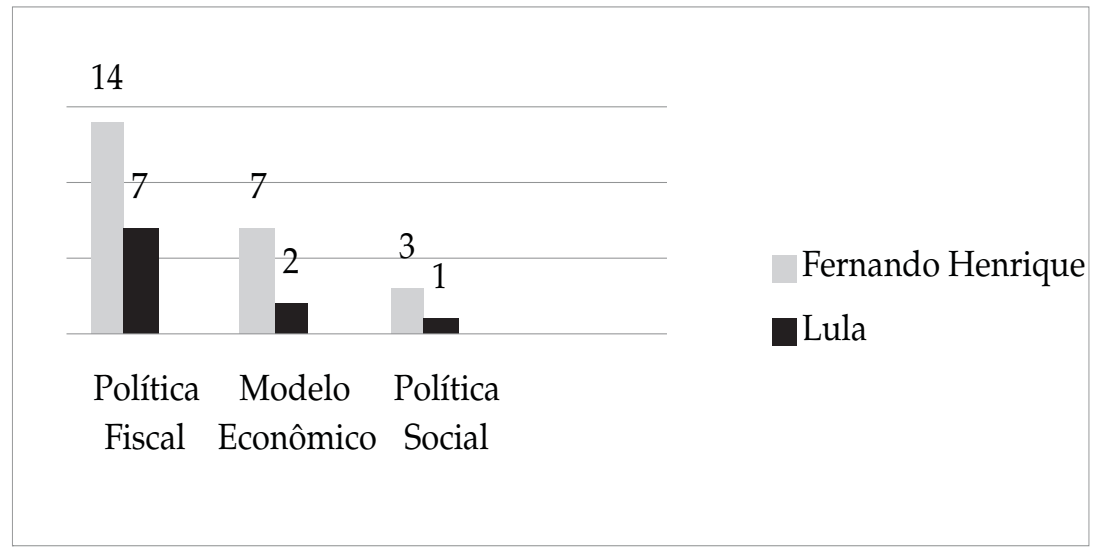

Elaboração da autora com base nas emendas à Constituição de 1988 (http://www.planalto.gov. br/ccivil_03/Constituicao/Constitui\%C3\%A7ao.htm).

Nota: O gráfico não apresenta a totalidade das emendas, apenas as que modificaram as regras das três principais políticas.

A reforma do modelo econômico, sobretudo a abertura ao capital privado e a quebra de monopólios, também recebeu do governo Fernando Henrique alta prioridade, embora sob o mandato do presidente Lula duas emendas sobre o tema tenham sido aprovadas, inclusive a EC no 40/2003, que autorizou a participação do capital estrangeiro no sistema financeiro nacional.

Ainda que, segundo afirmam, o presidente Lula tenha sido reeleito com a plataforma da política social para os segmentos mais pobres, as principais reformas constitucionais nessa área ocorreram durante o 
mandato do presidente Fernando Henrique Cardoso, embora a segunda reforma do ensino fundamental tenha expandido o escopo e os recursos da primeira, e o principal programa social do governo Lula - o Bolsa Família - seja financiado por recursos de um fundo proposto pelo Senado e com resistências iniciais do Executivo, como relatado adiante.

Se as regras constitucionais têm papel importante na produção das emendas, como será visto a seguir, não explicam sozinhas por que as reformas seguiram uma direção, e não outra. As emendas à Constituição de 1988 alteraram regras de políticas (fiscal, econômica e social) que demonstravam maior capacidade de adaptação a uma nova conjuntura doméstica e internacional decorrente do processo de evolução social, política e econômica em curso. A reforma dessas três políticas respondeu às demandas de uma conjuntura macroeconômica e política diferente da que guiou as decisões dos constituintes. Alguns analistas, todavia, tendem a afirmar a ocorrência de apenas uma causa. Esse é o caso de análises sobre as mudanças no marco das políticas públicas ocorridas no Brasil de autores como Melo (2002; 2005), Samuels e Mainwaring (2004) e Stepan (2000), que as creditaram à capacidade de liderança do presidente Fernando Henrique Cardoso (modelo de liderança ou intencional). De acordo com esses autores, o presidente Fernando Henrique foi capaz de contornar as restrições impostas pelo sistema político, entre elas o presidencialismo, o voto proporcional em lista aberta e o sistema federativo, o qual muitos vêem como pontos de veto das reformas e da governabilidade no Brasil. Alguns autores, como Kugelmas (2001), creditam as reformas ao retorno da tradição brasileira de presidentes fortes (modelo de recontratação), e Falleti (no prelo), analisando as reformas na área da saúde, a burocratas reformistas que gradualmente se infiltraram no aparelho governamental (modelo de evolução combinado com o de liderança de um grupo organizado).

$\mathrm{O}$ argumento que credita as reformas à liderança e às características pessoais do presidente Fernando Henrique parece hoje, no mínimo, incompleto. Isso porque, se a liderança pessoal pode, algumas vezes, exercer força extraordinária sobre processos políticos, mudanças constitucionais também ocorreram no governo do presidente Lula, que, do ponto de vista da liderança, pouco se assemelha ao de seu antecessor. Ademais, das quatorze emendas no mandato do presidente Fernando Henrique que incidiram, por exemplo, sobre a política fiscal, cinco fo- 
ram prorrogações da DRU e da CPMF. Isso não quer dizer que a agenda de reformas esteja concluída, em especial a tributária, mas sim que as reformas patrocinadas no mandato do presidente Fernando Henrique parecem ter dado conta da demanda do redesenho do modelo econômico e das políticas fiscal e social. Mais importante, no entanto, e como se está buscando demonstrar, a capacidade pessoal dos líderes na promoção de mudanças depende do contexto institucional (regras) e da conjuntura.

\section{Iniciativa}

A Constituição de 1988 adotou um modelo híbrido em relação à capacidade de iniciativa, dado que, pelo art. 60, ela pode ser emendada por proposta de um terço dos membros da Câmara ou do Senado, pelo presidente da República e por mais da metade das Assembléias Legislativas ${ }^{16}$.

Deputados e senadores juntos propuseram quase $60 \%$ das emendas (ver Tabela 2 abaixo). Embora o formato da Constituição brasileira seja o da supremacia do Legislativo, ou seja, emendas só podem ser aprovadas pelo Legislativo, a própria Constituição prevê a possibilidade de iniciativa de três atores políticos, distinguindo-se das duas constituições anteriores, as quais conferiram poder de iniciativa apenas a dois atores ${ }^{17}$. Maior número de atores com capacidade de iniciativa é outra variável que contribui para aumentar a probabilidade de emendas e, pelo modelo de Lutz (1994), para diminuir o índice de dificuldade do processo. Entretanto, e como será visto adiante, os legisladores federais, embora concentrem a maior parte das iniciativas do ponto de vista formal, têm sido pautados pela agenda de reformas do Executivo, com raras exceções.

Tabela 2

Emendas Constitucionais por Iniciativa

\begin{tabular}{l|c|c}
\hline Iniciativa & No de Emendas & \% \\
\hline Presidente da República & 21 & 37,5 \\
Senado & 10 & 17,8 \\
Câmara & 23 & 41,1 \\
Sem informação & 2 & 3,6 \\
\hline Total & $\mathbf{5 6}$ & $\mathbf{1 0 0 , 0}$ \\
\hline
\end{tabular}

Elaboração da autora com base nos dados da Câmara dos Deputados (http://www2.camara. gov.br/legislacao/pesquisa.html). 
A maior participação dos legisladores na proposição de emendas não quer dizer que essas emendas não tiveram o apoio do Executivo nem que este não tenha optado pela estratégia de ceder a Proposta de Emenda à Constituição - PEC a um parlamentar de sua base aliada ou mesmo aproveitar propostas antigas sobre o tema e que já tivessem sido iniciadas por parlamentares. Na verdade, muitas PECs iniciadas por parlamentares foram aproveitadas pelo Executivo. Esse foi o caso, por exemplo, de reformas importantes, como a segunda reforma do ensino fundamental, aprovada em 2006 pela EC no 53, que derivou de uma PEC de 1997 do deputado Valdemar da Costa Neto (Partido Liberal - PL-SP), assim como a reforma do sistema público de saúde (EC no 29), aprovada em 2000, que teve origem em uma PEC de 1995 de autoria do deputado Carlos Mosconi (Partido da Social Democracia Brasileira - PSDB-MG).

Algumas emendas resultaram do patrocínio de parlamentares ligados a grupos de interesse, mas foram posteriormente endossadas e parcialmente modificadas pelo Executivo. Esse foi o caso, por exemplo, da EC no 49/2006, que quebrou um monopólio da União, derivada de PEC apresentada em 2003 pelo senador Jorge Bornhausen (Partido da Frente Liberal - PFL-SC), a despeito de seu autor ser um oposicionista. A reforma do Judiciário, aprovada em 2004 (EC no 45), também teve trajetória semelhante: foi proposta em 1992 pelo jurista e então deputado Hélio Bicudo (Partido dos Trabalhadores - PT-SP). O mesmo ocorreu com propostas de Sérgio Arouca (EC no 11 / 1996) e Jandira Feghali (EC no 34/2001), que defendiam interesses dos profissionais dos órgãos de pesquisa e dos médicos.

O Executivo também negociou com parlamentares a proposição de emendas importantes para sua agenda tributária e fiscal: uma das reformas da previdência (EC no 47/2005) decorreu de PEC de uma senadora do partido do governo (Ideli Salvatti, PT-SC), assim como várias prorrogações da CPMF. Nesses casos, no entanto, os autores das iniciativas integravam a base partidária de apoio ao Executivo.

Contudo, algumas PECs ou algumas mudanças acrescentadas a PECs do Executivo nasceram no próprio Congresso, o que não significa que elas não contaram com o posterior apoio do Executivo nem que este não tenha participado de sua negociação ou proposto mudanças no texto original. Embora isso tenha ocorrido em apenas algumas emendas, sendo, portanto, exceções, mostra que em algumas poucas ques- 
tões o Legislativo foi capaz de aprovar, total ou parcialmente, a própria agenda. Isso aconteceu com um artigo que limita a edição de MPs (ECs nos 7 e 6/1995), acrescentado pelo Legislativo no decorrer dos debates de duas PECs do Executivo que definiam novas regras para a exploração de recursos minerais e para o transporte de cabotagem. Foi também o caso da EC no 48 / 2005 (diretrizes para um plano nacional de cultura) e da $E C$ no $26 / 2000$, que incluiu a moradia como um dos direitos sociais. Embora o conteúdo dessas duas últimas emendas não parecesse constar da agenda do Executivo, elas não foram por ele obstaculizadas, provavelmente em virtude de seu conteúdo mais normativo do que operacional.

Por fim, uma emenda merece maior atenção por causa de sua trajetória. Trata-se da PEC que criou o Fundo de Combate e Erradicação da Pobreza, de iniciativa do senador Antônio Carlos Magalhães, então presidindo o Senado, da qual resultou a EC no 31/2000. Pelas notícias vinculadas pela imprensa, essa PEC sofreu, no início, forte rejeição do Executivo e desencadeou tensões entre o presidente do Senado e o presidente da República. Várias foram as razões para o embate entre Antônio Carlos Magalhães, de um lado, e o presidente e o Ministério da Fazenda, de outro. Em primeiro lugar, ao propor a PEC, o senador já estava em conflito com o presidente Fernando Henrique, conflito que logo depois resultou no rompimento pessoal dos dois e, posteriormente, do PSDB com o PFL. Em segundo lugar, estava sendo discutida na Câmara a PEC do Executivo sobre a reforma tributária de 2001 (EC no 33). A PEC de Antônio Carlos Magalhães ia em direção oposta: incluía nos recursos do fundo 21 fontes de receita - sete remanejamentos de verbas, criação de três impostos, aumento nas alíquotas de três contribuições (a da CPMF, por exemplo), uma contribuição voluntária e sete novas fontes de renda. A primeira reação do presidente Fernando Henrique veio por intermédio do porta-voz do Planalto, afirmando, conforme publicou o jornal A Notícia, de 28/7/1999, que, no entender do presidente, "o lugar certo para se discutir o conjunto de propostas de ACMé a Câmara dos Deputados, dentro da emenda da reforma tributária".

Em outro momento, Fernando Henrique afirmou "que apenas um conjunto de políticas sociais renovadas - aliada à aprovação da legislação complementar da reforma da Previdência - poderá melhorar a transferência de recursos para as classes sociais menos favorecidas" (Jornal do Brasil, 3/8/1999). Antônio Carlos Magalhães contra-atacou afirmando que "propôs a criação de um fundo de combate à pobreza porque a tur- 
ma de FHC estava olhando só para a elite" (Veja, 5/4/2000). ACM também ameaçou declarando que, se não houvesse colaboração do presidente Fernando Henrique Cardoso para criar o fundo, o Congresso o criaria. A intermediação do Ministério da Fazenda e a presença do ministro Pedro Malan na audiência pública de discussão do fundo parecem ter sido cruciais não só para acalmar os ânimos dos dois líderes como também para adequar as fontes de recurso do fundo à política do governo ${ }^{18}$. No entanto, se a criação do fundo pode ser classificada como uma mudança causada por uma liderança do Congresso (modelo de liderança), sua aprovação só foi possível pelas regras do processo legislativo - dado que a designação do relator obedece à proporção das representações partidárias - e pela intermediação do Executivo. As regras do processo legislativo tornaram possível que o relator da emenda fosse um senador do PSDB, Lúcio Alcântara, o qual negociou com o Ministério da Fazenda e com Antônio Carlos Magalhães a elaboração de um substitutivo, garantindo a aprovação do fundo, mas mudando completamente suas receitas, tal como propunha o Ministério da Fazenda.

Ainda no que se refere à iniciativa, a Tabela 3 mostra que, no primeiro mandato do presidente Fernando Henrique e no segundo mandato do presidente Lula, as iniciativas do Executivo representaram o dobro das iniciativas do Legislativo, enquanto nos demais anos as iniciativas do Legislativo sempre superaram, de longe, as do Executivo.

Tabela 3

Iniciativas de PECs por Mandato Presidencial e por Presidente

\begin{tabular}{l|c|c|c}
\hline Presidente/Mandato & $\begin{array}{c}\text { No de Emendas } \\
\text { Aprovadas de } \\
\text { Iniciativa do } \\
\text { Executivo }\end{array}$ & $\begin{array}{c}\text { No de Emendas } \\
\text { Aprovadas de } \\
\text { Iniciativa do } \\
\text { Legislativo }\end{array}$ & Total \\
\hline Collor (até 10/1992) & - & 2 & 2 \\
Franco (10/1992-1994) & - & 2 & 2 \\
FHC I (1995-1998) & 11 & 5 & 16 \\
FHC II (1999-2002) & 5 & 12 & 17 \\
Lula I (2003-2006) & 3 & 11 & 14 \\
Lula II (2007-..) & 2 & 1 & 3 \\
Sem informação & - & - & 2 \\
\hline Total & $\mathbf{2 1}$ & $\mathbf{3 3}$ & 56 \\
\hline
\end{tabular}

Elaboração da autora com base nos dados da Câmara dos Deputados (http://www2.camara. gov.br/legislacao/pesquisa.html).

Por conteúdo das iniciativas, todas as importantes reformas realizadas no primeiro mandato do presidente Fernando Henrique - previdência, 
administrativa, tributária e fiscal -, assim como mudanças no modelo econômico, foram de iniciativa do Executivo, com exceção das prorrogações da CPMF. O mesmo aconteceu no governo Lula com as duas emendas que alteraram questões tributárias aprovadas em seu mandato (ECs no 44/2004 e no 42/2003), mas não com a reforma da previdência (EC no $47 / 2005)$.

\section{Número de Palavras}

O número de palavras das constituições é usado como uma proxy do grau de constitucionalização. Quando promulgada, a Constituição de 1988 continha, no corpo constitucional, 41.529 palavras e 8.151 no capítulo do ADCT, totalizando 49.680. Com as emendas, passou para 49.202 palavras no corpo da Constituição e para 15.780 no ADCT, totalizando 64.982 palavras, um acréscimo de $13 \%$ incidente principalmente sobre o $\mathrm{ADCT}^{19}$. A Constituição de 1988 também supera em número de palavras as duas constituições anteriores: a de 1967-1969 continha 38.905 palavras; a de 1946, 22.395.

Quanto ao número de artigos, a Constituição continha, em 1988, 245 artigos mais 70 no capítulo do ADCT. Com as emendas, o corpo constitucional foi pouco expandido, passando a contar com 250 artigos, mas o mesmo não ocorreu com o capítulo do ADCT, que passou a ter 95 arti$\operatorname{gos}^{20}$. O maior crescimento de emendas incluídas no ADCT mostra que as reformas tendem a ser mais temporárias do que permanentes, notadamente as incidentes sobre a política fiscal.

Esses números mostram a tendência dos constituintes brasileiros em diferentes momentos políticos e históricos de constitucionalizar grande número de matérias. Esse é um forte indicador da visão dos constituintes de que as constituições brasileiras não regeriam apenas princípios e direitos, mas teriam o papel de um código de regras. A Constituição de 1988 radicalizou essa visão, assim como as emendas sobre política fiscal e políticas sociais. Para que tal visão fosse possível, seria necessária a adoção de regras relativamente fáceis para reformar e/ou detalhar questões constitucionalizadas.

\section{Constitucionalização}

Ao lado do número de palavras, outra variável que permite predizer o que ocorrerá com a Constituição é seu conteúdo, ou seja, a constitucionalização ou não de matérias que seriam objeto de legislação ordiná- 
ria, ou de maioria simples, para sua aprovação ${ }^{21}$. Todavia, essa constitucionalização não é incomum, dado que alguns países que reescreveram suas constituições nos anos recentes apresentam tendência semelhante. A Constituição brasileira segue, assim, a tendência mundial de constitucionalização de matérias que seriam objeto de legislação infraconstitucional ou ordinária, como mencionado acima ${ }^{22}$.

No caso da Constituição de 1988, o aumento da constitucionalização manteve a trajetória das constituições anteriores, iniciada com a de 1934, na qual, pela primeira vez e por influência da Constituição de Weimar, foram incluídas provisões sobre atividades econômicas e direitos individuais e coletivos, inclusive sobre a família, direitos trabalhistas e servidores públicos. A relativa novidade da Constituição de 1988 é que, ao lado de princípios, regras e direitos - individuais, coletivos e sociais -, se ampliou a constitucionalização das políticas públicas, notadamente por meio das emendas que detalharam as políticas de educação e saúde. Aumentou também o número de matérias de competência legislativa privativa da União de 21 itens na Constituição de 1967-1969 para 29 na de 1988.

\section{Mudanças de Contexto/Conjuntura}

Embora as variáveis selecionadas tenham demonstrado capacidade explicativa sobre como e por que ocorreram emendas à Constituição de 1988, o conteúdo das emendas constitucionais (Quadro 1 e Gráfico 1) deixa claro que reformas no sistema fiscal e no modelo econômico foram objeto das maiores mudanças, tanto qualitativa quanto quantitativamente, apontando, portanto, para a importância da variável mudanças de contexto/conjuntura. Isso significa que não apenas as regras estabelecidas na Constituição de 1988 criaram os incentivos para as mudanças, mas também que uma conjunção de fatores, notadamente a adaptação dos mandamentos constitucionais a um novo contexto político e econômico, teve papel decisivo nas reformas ocorridas a partir dos anos 1990.

A mudança de rota pode ser creditada às conjunturas macroeconômica e política internacional e doméstica. Os fatores macroeconômicos criaram as condições para a adoção de uma política mais próxima da agenda da globalização - abertura ao capital privado, diminuição do papel e da intervenção do Estado na economia, adaptação do país para sua inserção na economia mundial, entre outras. Aliadas a esses fatores ex- 
ternos, as mudanças, tanto as iniciais quanto as subseqüentes, foram mantidas e ampliadas dado o consenso entre as elites políticas da importância da sustentabilidade da estabilização monetária iniciada com o Plano Real. Posteriormente, e como conseqüência da estabilidade monetária, as elites políticas encontraram as condições favoráveis para transformar alguns direitos sociais constitucionalizados em políticas e ações. Isso mostra que não apenas as regras, como afirma parte da literatura sobre emendas constitucionais, mas também as mudanças de contexto/conjuntura explicam as alterações constitucionais. Assim, os contextos político e macroeconômico mostraram, no caso do Brasil, ter importância equivalente à das regras ${ }^{23}$.

Como argumentei em outros trabalhos (Souza, 1997; 2001; 2005), os constituintes de 1988 concentraram seus esforços na criação de regras capazes de legitimar o novo regime democrático, enquanto a agenda sobre questões de natureza macroeconômica e fiscal refletia as incertezas daquele momento. No entanto, essa agenda se tornou dominante nos governos a partir do início dos anos 1990 não só no Brasil, mas na maioria dos países. Assim, as emendas aprovadas a partir de meados dos anos 1990 buscaram adaptar o país à mudança do contexto internacional e doméstico reformando regras sobre questões que não estavam na agenda nem dos constituintes nem da transição democrática, tais como a globalização e o ajuste fiscal. A relativa facilidade do processo de "emendamento" tornou possível a adaptação ao novo contexto/conjuntura.

Embora não seja objetivo deste artigo discutir as conseqüências políticas das mudanças constitucionais, uma deve ser destacada: o fortalecimento da capacidade de o governo federal formular políticas. Isso foi possível porque, como argumentei em outros trabalhos (Souza, ibidem), a Constituição de 1988, em seu formato original, adotou dois caminhos paradoxais: por um lado descentralizou recursos e vinculou receitas da União a setores, políticas e regiões (estima-se que cerca de $80 \%$ dos recursos federais são vinculados a algum tipo de despesa, seja por determinação constitucional, seja decorrente de lei); por outro, não só manteve mas também ampliou o rol de competência da União, assim como a lista de matérias sobre a qual a União tem competência privativa para legislar, o que significa competência exclusiva para determinar preferências e definir o desenho das políticas públicas. 


\section{CONSIDERAÇÕES FINAIS}

Neste artigo foram analisadas as emendas constitucionais e de revisão promulgadas entre 1992 e 2008 à luz de duas variáveis: 1) regras constitucionais e conteúdo da Constituição, que indicam o grau de previsibilidade de mudanças no texto original, e2) causalidade das mudanças.

Fatores institucionais e não-institucionais explicam a alta ocorrência de emendas constitucionais: regras de "emendamento" relativamente fáceis de serem cumpridas; tamanho da Constituição; agenda dos constituintes concentrada na restauração e na legitimação do sistema democrático; advento de uma nova agenda, que requeria mudanças no modelo econômico e na política fiscal; estabilidade monetária, que permitiu a transformação de direitos sociais em políticas públicas, cedendo às esferas subnacionais, sobretudo às locais, sua implementação.

Conclui-se que a Constituição de 1988 resultou do momento político marcado pelo objetivo de tornar crível e de legitimar o novo sistema democrático, dado que foi desenhada antes do fim da transição. Não por acaso, das 62 emendas, apenas duas mudaram as regras iniciais aplicáveis ao sistema político. No entanto, o desenho das políticas sociais e fiscais caminhou em direção oposta à da estabilidade. Isso porque, em virtude do objetivo legitimador da Constituição, negociações e barganhas referentes às políticas públicas e que encaminhassem alternativas para questões que afetavam as condições sociais da população e o desempenho macroeconômico do país foram marcadas por incertezas quanto a suas possibilidades.

As emendas promulgadas a partir dos anos 1990 buscaram, então, desenhar novas políticas macroeconômicas, implementar um modelo econômico mais próximo do paradigma mundial vigente e pôr em prática mandamentos constitucionais relativos às políticas sociais (descentralização, participação, universalização) que não puderam ser negociados durante a transição.

Todavia, e diferentemente do que ocorreu com as regras do sistema democrático e do sistema político, várias políticas públicas aprovadas por emenda constitucional têm uma marca pouco estudada: elas são datadas, isto é, requerem novas emendas constitucionais e o retorno ao Congresso para sua continuidade ${ }^{24}$. Dessa forma, o Legislativo não delegou ao Executivo - tampouco o Executivo propôs - a decisão sobre o 
tempo de duração de algumas políticas públicas, fazendo-as retornar ao debate nacional e ao conflito político periodicamente, o que requer, portanto, novas emendas à Constituição.

A alta taxa de "emendamento" da Constituição de 1988 em relação à de outros países, no entanto, não confirma vários temores de parte da literatura. $\mathrm{O}$ primeiro seria o de que mudanças constantes nas regras do jogo trazem incertezas aos atores econômicos. Na verdade, as mudanças no modelo econômico abriram mais oportunidades para os investidores, tanto nacionais quanto estrangeiros. O segundo é o de que mudanças poderiam fortalecer o Executivo e prorrogar indefinidamente $o$ mandato de seus dirigentes, o que seria perigoso em países de democracia recente, pela possibilidade de estimular abusos de poder e limitar conquistas democráticas e direitos individuais e coletivos. No caso brasileiro, a emenda da reeleição dos ocupantes de cargos no Executivo foi limitada a mais um mandato e não ocasionou, até o momento, ausência de rotatividade partidária nos Executivos dos três níveis. Ademais, as conquistas democráticas e os direitos individuais, coletivos e sociais não foram limitados, sendo que as emendas foram as que tornaram efetivos alguns direitos sociais. O terceiro seria o de que a Constituição brasileira, por sua extensão e conteúdo (constitucionalização de políticas e direitos), impediria a governabilidade. Não só isso não ocorreu, como as regras constitucionais permitiram a adaptação do país a uma nova agenda doméstica e internacional.

Dessa forma, pode-se concluir que, ao desenharem uma Constituição que refletia a agenda política e econômica do país na fase da redemocratização, os constituintes brasileiros "desataram as mãos" dos futuros parlamentares e do Executivo, autorizando-os a fazer mudanças e adaptações no que não foi possível negociar naquele "momento crítico".

(Recebido para publicação em setembro de 2008) (Versão definitiva em janeiro de 2009) 


\section{Celina Souza}

\section{NOTAS}

1. Algumas exceções: Melo (2002; 2005; 2007), Gomes (2006) e Souza (1997; 2005), por exemplo. Até onde tenho conhecimento, Cláudio Couto e Rogério Arantes são os únicos cientistas políticos que desenvolveram uma linha de pesquisa sistemática sobre as mudanças da Constituição de 1988 aplicando um método próprio de análise constitucional para explicar suas inúmeras reformas. Ver Couto e Arantes (2003; 2006) e Arantes e Couto (2008).

2. Motivados pelos 20 anos da Constituição de 1988, vários cientistas políticos e instituições de pesquisa analisaram ou estão analisando o processo constituinte e/ou temas constitucionais relacionados ao sistema político e a políticas específicas. Ver, por exemplo, Oliven, Ridenti e Brandão (2008), Limongi (2008), Pilatti (2008) e Praça e Diniz (2008). O Centro de Estudos de Cultura Contemporânea - Cedec desenvolve um projeto de pesquisa intitulado A Constituição de 1988: Teoria e Prática.

3. Sobre o tema das mudanças sociais à luz da teoria da escolha racional e da economia política, ver, entre outros, Knight e Sened (1995).

4. Como mostra Ferejohn (1997), a literatura da ciência política que trata de constituições defende o argumento de que o remédio para essas tensões e dilemas é tornar o processo de emendas relativamente fácil. No mesmo veio, a teoria de desenho institucional advoga que as instituições devem conter mecanismos de revisão para poder responder às transformações relevantes (Goodin, 1998:40) e para preservar a própria estabilidade (Offe, 1998).

5. No caso da Constituição de 1988 , as cláusulas pétreas listadas no parágrafo $4^{-}$do art. 60 são a forma federativa; o voto direto, secreto, universal e periódico; a separação dos Poderes e os direitos e garantias individuais. Na Constituição de 1967-1969, a única cláusula pétrea era a forma federativa do Estado; na de 1946, a forma federativa e a República.

6. Ferejohn (1997) chama a atenção para a importância do contexto histórico nas análises sobre desenho constitucional porque só assim será possível explicar por que as constituições estão cada vez mais incorporando matérias de legislação ordinária. Para uma análise dos contextos histórico, político, social e econômico das sete constituições brasileiras, ver, entre outros, Souza (1997; 2001; 2002).

7. Pelo modelo de Lutz (1994), constituições que requerem ratificações por Estados ou referendo popular seriam as menos emendadas. Ferejohn (1997), no entanto, reviu o sistema de pontuação de Lutz e contestou essa conclusão. Para Ferejohn, apenas os procedimentos do processo legislativo - supermaiorias, maioria em mais de uma sessão legislativa e bicameralismo - afetam a taxa de "emendamento", e não as ratificações ou os referendos.

8. Em 1993, ocorreu o plebiscito, previsto na própria Constituição, para que os eleitores decidissem sobre a forma de governo (república ou monarquia constitucional) e o sistema de governo (parlamentarista ou presidencialista). Como as mudanças não foram aprovadas, o plebiscito não gerou nenhuma emenda constitucional.

9. São direitos sociais a educação, a saúde, o trabalho, a moradia, o lazer, a segurança, a previdência social, a proteção à maternidade e à infância e a assistência aos desamparados (art. $\left.6^{\mathrm{O}}\right)$. 
10. A questão sobre a divisão "ótima" entre o que deve ou não ser constitucionalizado é matéria de amplo debate, sobretudo entre juristas e economistas da área fiscal. Sobre esse debate entre juristas norte-americanos, ver Valente et alii (2001). Para uma análise sobre o crescimento da constitucionalização de direitos - individuais, coletivos e sociais -, a maioria por meio de reformas nas constituições, gerando sua judicialização, ver Hirschl (2004). Para uma discussão sobre a chamada judicialização da política ou do papel do Judiciário como ator político no Brasil pós-1988, ver Sadek (2008), Taylor (2007) e Werneck Vianna (2002), entre outros.

11. A Constituição brasileira de 1969, e não a de 1988, foi incluída na lista dos 32 países analisados por Lutz (1994).

12. A Constituição de 1946 determinava a regra da maioria absoluta em duas sessões ordinárias e consecutivas nas duas Casas legislativas. Se a emenda fosse aceita em uma das Casas por dois terços de seus membros, seria logo submetida à outra e aprovada pelo mesmo trâmite, caso atingisse igual maioria.

13. Nos países do Leste Europeu, os testes de Roberts (no prelo) mostraram que o índice de dificuldade foi significante no número de emendas, mas não em seu tamanho.

14. A Constituição da Venezuela, que também obteve índice alto de dificuldade pelo sistema de Lutz (4,75), foi completamente modificada, como mostrou Melo (2007).

15. Essa interpretação diverge de Melo (2007:253) e de Arantes e Couto (2008:60), que creditam a diminuição do número de emendas à maior dificuldade do presidente Lula, em comparação com o presidente Fernando Henrique, de formar maiorias qualificadas no Congresso.

16. Como se sabe, a prerrogativa das Assembléias Legislativas ainda não foi exercida.

17. Na Constituição de 1967-1969, o presidente e os membros do Congresso tinham poder de iniciativa. Na de 1946, o poder de iniciativa era restrito ao Legislativo: Congresso e Assembléias Legislativas; estas podiam propor emendas por um período de dois anos após a promulgação da Constituição.

18. O Ministério da Fazenda chegou a divulgar uma nota pública elogiando a criação do fundo, mas expressando suas preocupações e sugerindo mudanças. Ver http:// www.agenciabrasil.gov.br.

19. Usando outro método, Arantes e Couto (2008:59) estimaram um crescimento de $25 \%$ ou mais da Constituição.

20. Como nos ensinam os constitucionalistas, as disposições transitórias de uma Constituição têm por objetivo regulamentar o período de transição entre normas jurídicas. São, portanto, afeitas ao direito intertemporal. Há algumas características do ADCT que o diferencia do resto da Constituição. Entre essas, a mais marcante é a de que os dispositivos do ADCT são feitos para durar por período determinado, sendo, portanto, efêmeros. Isso não significa, todavia, que todo o conteúdo do ADCT seja transitório, mas sim que tende à efemeridade, o que talvez signifique que a "boa" técnica constitucional não esteja sendo seguida.

21. Sartori classificou a Constituição brasileira de 1988 como uma "novela do tamanho de uma lista telefônica" (1994:199), eivada de "temas triviais, promessas inalcançáveis e provisões quase suicidas" (ibidem). Para uma discussão dessas e de outras sombrias previsões de Sartori, ver Melo (2007). 


\section{Celina Souza}

22. Para descrições e análises sobre as características constitucionais de alguns países federais, ver Kincaid e Tarr (2005).

23. Roberts (no prelo) argumenta que os contextos político e social assumiram maior importância nas reformas constitucionais dos países do Leste Europeu do que as regras. A mudança de contexto foi por ele creditada à dinâmica da transição política e a pressões internacionais.

24. Em seus diversos artigos, Cláudio Couto e Rogério Arantes propõem um argumento diverso, ou seja, cada governante se vê diante da necessidade de emendar a Constituição de 1988 para implementar suas plataformas de governo ou suas políticas públicas (policies).

\section{REFERÊNCIAS BIBLIOGRÁFICAS}

ARANTES, Rogério B. e COUTO, Cláudio G. (2008), "A Constituição Sem Fim”, in S. Praça e S. Diniz (orgs.), Vinte anos de Constituição. São Paulo, Paulus, pp. 31-60.

BUCHANAN, James M. e TULLOCK, Gordon. (1962), The Calculus of Consent: Logical Foundations of Constitutional Democracy. Ann Arbor, University of Michigan Press.

CONGLETON, Roger D., KYRIACOU, Andreas e BACARIA, Jordi. (2003), “A Theory of Menu Federalism: Decentralization by Political Agreement". Constitutional Political Economy, vol. 14, no 3, pp. 1043-4062.

COUTO, Cláudio G. e ARANTES, Rogério B. (2003), “Constituición o Políticas Públicas? Una Evaluación de los Años FHC", in V. Palermo (org.), Política Brasileña Contemporánea: De Collor a Lula en Años de Transformación. Buenos Aires, Siglo XXI.

. (2006), "Constituição, Governo e Democracia no Brasil". Revista Brasileira de Ciências Sociais, vol. 21, no 61, pp. 41-62.

ELSTER, Jon. (1983), Explaining Technical Change. Cambridge, Cambridge University Press.

FALLETI, Tulia. (no prelo), “Infiltrating the State: The Evolution of Health Care Reforms in Brazil, 1964-1988".

FEREJOHN, John. (1997), "The Politics of Imperfection: The Amendment of Constitutions". Law and Social Inquiry, vol. 22, no 2, pp. 501-531.

GOMES, Sandra. (2006), “O Impacto das Regras de Organização do Processo Legislativo no Comportamento dos Parlamentares: Um Estudo de Caso da Assembléia Nacional Constituinte (1987-1988)". DADOS, vol. 49, no 1, pp. 193-224.

GOODIN, Robert (org.). (1998), The Theory of Institutional Design. Cambridge, Cambridge University Press.

HIRSCHL, Ran. (2004), Towards Juristocracy: The Origins and Consequences of New Constitutionalism. Cambridge, Mass e London, Harvard University Press. 
KINCAID, John e TARR, Alan (orgs.). (2005), Constitutional Origins, Structure, and Change in Federal Countries. Montreal, McGill.

KNIGHT, Jack e SENED, Itai. (1995), Explaining Social Institutions. Ann Arbor, University of Michigan Press.

KUGELMAS, Eduardo. (2001), "A Evolução Recente do Regime Federativo no Brasil”, in W. Hofmeister e J. M. Brasiliense Carneiro (orgs.), Federalismo na Alemanha e no Brasil. São Paulo, Konrad Adenauer.

LIJPHART, Arend. (1999), Patterns of Democracy: Government Forms and Performance in Thirty-Six Countries. New Haven, Yale University Press.

LIMONGI, Fernando. (2008), “O Poder Executivo na Constituição de 1988”, in R. G. Oliven, M. Ridenti e G. M. Brandão (orgs.), A Constituição de 1988 na Vida Brasileira. São Paulo, Anpocs.

LUTZ, Donald S. (1994), "Toward a Theory of Constitutional Amendment". American Political Science Review, vol. 88, no 2, pp. 355-370.

MELO, Marcus André. (2002), Reformas Constitucionais no Brasil: Instituições Políticas e Processo Decisório. Rio de Janeiro, Revan.

. (2005), “O Sucesso Inesperado das Reformas de Segunda Geração: Federalismo, Reformas Constitucionais e Política Social”. DADOS, vol. 48, no 4, pp. 845-889.

(2007), "Hiper-Constitucionalização e Qualidade da Democracia: Mitos e Realidade", in C. R. Melo e M. Alcántara Aaez (orgs.), A Democracia Brasileira: Balanço e Perspectivas para o Século 21. Belo Horizonte, Editora UFMG, pp. 237-267.

NORTH, Douglass e WEINGAST, Barry. (1989), "Constitutions and Commitment: The Evolution of Institutions Governing Public Choice in 17th Century England". Journal of Economic History, vol. 49, pp. 803-832.

OFFE, Claus. (1998), “Designing Institutions in East European Countries", in R. Goodin (org.), The Theory of Institutional Design. Cambridge, Cambridge University Press, pp. 199-226.

OLIVEN, Ruben G., RIDENTI, Marcelo e BRANDÃO, Gildo Marçal (orgs.). (2008), A Constituição de 1988 na Vida Brasileira. São Paulo, Anpocs.

PILATTI, Adriano. (2008), A Constituinte de 1987-1988: Progressistas, Conservadores, Ordem Econômica e Regras do Jogo. Rio de Janeiro, Editora PUC-Rio/Lumen Juris.

PRAÇA, Sérgio e DINIZ, Simone (orgs.). (2008), Vinte Anos de Constituição. São Paulo, Paulus.

RIKER, William. (1982), Liberalism Against Populism. Illinois, Waveland Press.

ROBERTS, Andrew. (no prelo), "The Politics of Constitutional Amendment in Eastern Europe". Constitutional Political Economy.

ROTHSTEIN, Bo. (1998), "Political Institutions: An Overview”, in R. Goodin e H.-Dieter Klingemann (orgs.), A New Handbook of Political Science. Oxford, Oxford University Press, pp. 133-166.

SADEK, Maria Tereza A. (2008), "Poder Judiciário: Conservação e Mudanças", in S. Praça e S. Diniz (orgs.), Vinte Anos de Constituição. São Paulo, Paulus, pp. 61-76. 


\section{Celina Souza}

SAMUELS, David J, e MAINWARING, Scott. (2004), “Strong Federalism, Constraints on the Central Government, and Economic Reform in Brazil", in E. Gibson (org.), Federalism and Democracy in Latin America. Baltimore, Johns Hopkins University Press, pp. 85-130.

SARTORI, Giovanni. (1994), Comparative Constitutional Engineering: An Inquiry into Structures, Incentives and Outcomes. London, Macmillan.

SOUZA, Celina. (1997), Constitutional Engineering in Brazil: The Politics of Federalism and Decentralization. London/NewYork, Macmillan/St. Martin's Press.

. (2001), “Federalismo e Descentralização na Constituição de 1988: Processo Decisório, Conflitos e Alianças". DADOS, vol. 44, no 3, pp. 513-560.

. (2002), “Brazil: The Prospects of a Center-Constraining Federation in a Fragmented Polity". Publius: The Journal of Federalism, vol. 32, no 2, pp. 23-48.

. (2005), “Federalismo, Desenho Constitucional e Instituições Federativas no Brasil Pós-1988". Revista de Sociologia e Política, no 24, pp. 105-121.

STEPAN, Alfred. (2000), “Brazil’s Decentralized Federalism: Bringing Government Closer to the Citizens?" Daedalus, vol. 129, № 2, pp. 145-169.

TAYLOR, Matthew. (2007), “O Judiciário e as Políticas Públicas no Brasil”. DADOS, vol. 50, no 2, pp. 229-257.

VALENTE, William et alii. (2001), Cases and Materials on State and Local Government Law. St. Paul, West Group.

WERNECK VIANNA, Luiz (org.). (2002), A Democracia e os Três Poderes no Brasil. Belo Horizonte/Rio de Janeiro, Editora da UFMG/Iuperj. 


\section{ABSTRACT \\ Rules and Context: Amendments to the 1988 Brazilian Constitution}

Why do institutions change, and why, how, and on what subjects have changes occurred in the 1988 Brazilian Constitution? The article raises two hypotheses. The first assumes that the rules of amendment to the 1988 Constitution reflect the original framers' uncertainties on some issues. The second refers to the causes of changes, that is, contending that the constitutionalization of numerous issues was followed by changes in Brazil's macroeconomic and political context, allowing for the redesign of various Constitutional provisions. The article concludes that by designing a Constitution that reflected the redemocratization agenda, the framers "untied the hands" of future legislators and Presidents, facilitating the rules for Constitutional amendments and allowing Brazil's adaptation to a new context.

Key words: Brazil; 1988 Constitution; constitutional amendments

\section{RÉSUMÉ}

Règles et Contexte: Les Réformes de la Constitution Brésilienne de 1988

Pourquoi les institutions changent-elles? Pourquoi, comment et quelles matières de la Constitution brésilienne de 1988 ont subi des modifications? Dans cet article, on discute deux hypothèses: la première, c'est que les règles d" "amendement" de cette Constitution reflètent les incertitudes des constituants sur certaines matières. Dans la seconde, on considère la causalité des changements, c'est-à-dire que la constitutionnalisation en certaines matières a été suivie de changements du contexte macro-économique et politique, ce qui a permis la modification de certains articles de la Constitution. En conclusion, on voit que les constituants, en rédigeant un texte qui traduisait le programme de redémocratisation, ont permis aux futurs parlementaires et au pouvoir exécutif de mieux travailler des règles en vue du changement constitutionnel et de l'adaptation du pays à son nouveau contexte.

Mots-clé: Brésil; Constitution de 1988; amendements constitutionnels 